\title{
THE PLACE OF TURKISH CULTURE OF THE LIFE IN HOUSING DESIGN \\ "EXAMPLE OF TURKISH HOUSES IN CYPRUS DURING THE OTTOMAN PERIOD”
}

\author{
Zihni TURKAN \\ Yakın Doğu Üniversitesi, Kıbrıs \\ zturkan@,analiz.net
}

\begin{abstract}
The house has been a sanctuary as the sum of places designed for the functions of life and enabling the family, the smallest of communities, to live together. People's needs for shelter can be holistic in containing physical adequacy of living quarters as well as their social and psychological adequacies. Various criteria, such as the number of family members, spatial needs, inner-outer space relations, auxiliary spaces, construction quality, and conditions of comfort are programmed and shaped within the life cultures of communities. Spaces in Traditional Turkish House, shaped with the Turkish life culture, are designed in accordance with the living styles and traditions of the Turkish people, and provided social and psychological adequacy. Traditional Turkish Houses, among the Ottoman Period in Cyprus constructed in the style of Turkish Architecture, still constitute an important element of the present day historical texture. Generally having two floors and an atrium (yard), these houses were built in adjacent form, lining down the street, and gave a style to the texture of the street with their plain facades, oriels brimming over the street, and wide fringes. Room in the Turkish Houses in Cyprus, was designed as a multi-purpose abode where day and night functions were realized, the same way it was in the tents during the nomadic life of Turks. Main room was used as the guest room, in accordance with the importance of guests in the Turkish traditions. The importance of family in the culture of Turkish life, made the hall important, as the common abode, the meeting place, into which other rooms opened. Outer halls, or colonnades, with riwaqs, enabling the house-atrium relationship, created the type of plan for the Ottoman Period houses. The staircase, connection the floors were in a position unseen from the main entrance of the house, and generally ran parallel to the hall. The atrium, or yard, has been important in the houses in Cyprus, due to the connection of Turks to nature and earth, from their past. Elements of aquatic architecture, such as well, fountain, water tank, provided the water needed for the house and yard. The formation of abodes of the Turkish Houses during the Ottoman Period in Cyprus (1570-1878) found its expression within the needs of the dwellers life culture, thus serving in accordance with the lives of the household.
\end{abstract}

Keywords: Cyprus, Ottoman, home, Turkish House, hall.

\section{TÜRK YAȘAM KÜLTÜRÜNÜN KONUT TASARIMINDAKİ YERİ “KIBRIS'TA OSMANLI DÖNEMI TÜRK EVLERİ ÖRNEĞI"}

ÖZ

Konut, en küçük topluluk olan ailenin, birarada yaşam sürmesine olanak sağlayan ve yaşam fonksiyonları için düzenlenen mekânlar toplamı olarak insanlar için barınak teşkil etmektedir. İnsanların barınma gereksinimleri, yaşam mekânlarının fiziki yeterliliği yanı sıra sosyal ve psikolojik yeterlilikleri ile bütün olabilmektedir. Ailelerin üye sayıları, mekânsal gereksinimler, iç-dış mekân ilişkileri, yardımcı mekânlar, yapı kalitesi ve konfor koşulları gibi birçok kriter, toplumların yaşam kültürleri ile programlanıp biçim bulmaktadır. Türk yaşam kültürü ile biçimlenen Geleneksel Türk Evi'ndeki mekânlar da Türklerin yaşam tarzlarına ve geleneklerine uygun olarak tasarlanıp, sosyal ve psikolojik yeterlilik sağlamıştır. Kıbrıs’ta Osmanlı Dönemi’ne ait Türk Mimarisi tarzındaki birçok eser arasında bulunan Geleneksel Türk Evleri, halen günümüzdeki tarihi dokunun önemli bir ögesini teşkil etmektedirler. Genellikle iki katlı ve avlulu olan evler, bitişik nizamda ve yalın cepheleri, sokağa taşan cumbaları, geniş saçakları ile sokak boyunca dizilmekte ve sokak dokusuna da biçim vermektedirler. 
Kıbrıs'taki Türk Evleri'nde Oda; Türklerin göçebe yaşamındaki çadırda olduğu gibi gündüz ve gece fonksiyonlarının gerçekleştiği çok amaçlı bir mekân olarak tasarlanmıştır. Evin en önemli ve en iyi konumlu odası olan Başoda da Türk geleneklerindeki önemi gereği misafir odası olarak kullanılmıştır. Türk yaşam kültüründe ailenin önemi; odaların açıldığı bir buluşma alanı, ortak mekân olarak Sofayı önemli kılmıştır. Kıbrıs'ın iklimsel özellikleri ile uyumlu ve ev - avlu ilişkisini sağlayan revaklı Dış Sofalar, Osmanlı Dönemi evlerinin plan tipini oluşturmuştur. Katları birbirine bağlayan merdiven ise evlerin ana girişinden görülemeyecek konumda ve çoğunlukla Sofaya paralel olarak uzanmaktadır. Avlu, Türklerin geçmişten itibaren doğayla, toprakla olan bağları nedeniyle Kıbrıs'taki evlerde de önemli olmuştur. Avlularda yer alan; kuyu, çeşme, su deposu gibi su mimarisi ögeleri, evin ve avlunun su gereksinimini karşılamıştır. Kıbrıs'ta Osmanlı Dönemi (1570-1878) Türk Evlerinin mekân oluşumları, kullanıcılarının yaşam kültürünün gerekleriyle ifade bulmuş ve böylece ev halkının yaşamına uyumlu olarak hizmet vermiştir

Anahtar Kelimeler: Klbrls, Osmanl, konut, Türk Evi, sofa.

\section{INTRODUCTION}

A house, besides being the basic notion of space satisfying the human need for housing, also has an important place in human life physically, socially, and psychologically. In literature, 'house' is defined as a "place, shelter, which protects people from the physical effects of the environment." However, from what we learn from history, it can be seen that different cultures of communities causing different life activities, have been effective in shaping their vital abodes. The statement "A house is a social occurrence, and the feature of houses is defined by the psycho-social structure of the community" puts emphasis on the basic contributing factor in house designing (Ş.Ö.Gür 1993:13).

The housing phenomenon, which began with the caves and hollow trees in the primitive ages of human history, showed a development of construction after the Neolithic Age, with places shaped to meet special needs, and reached the shapes of today. The culture of living, acquired through groups of people moving from company to community, provided social and psychological adequacy for life activities by becoming the most important effect in the creation and shaping of the criteria of house design (Ş.Ö.Gür 2000:91). With its unique traditions, visible since their history in Central Asia, Turkish life culture gave a form to the vital abodes of Turks, and as they moved from nomadic life to permanent settlements, the house replacing the tent, as a work of construction, brought about the Traditional Turkish House model, within its internal development. The effects of Turkish life culture can be seen in the planning of Turkish Houses (S. H. Eldem 1968:11). Houses, with multi-functional rooms, halls, and yards, corresponding to the Turkish life style and traditions, and designed in accordance with necessary functions, served their users for many years.

\section{OTTOMAN PERIOD TURKISH HOUSES IN CYPRUS}

During the Ottoman Period, which began with the Ottomans capturing Cyprus from the Venetians in 1570 and lasting until 1878, many buildings were constructed in the Turkish architectural style, which left their mark on the historical texture of Cyprus today. Traditional Turkish House style buildings have an important place among the works of art, such as mosques, convents, inns, baths, fountains, and houses. Many of these houses still surviving are within the walled city of Nicosia, where the historical texture is present (Anonymous 1982: vi).

Just like with other Turks in the world, in the social history of the Turkish community in Cyprus, the importance, and holiness of the family, its unity under the roof, and the importance of relationships with neighbors, played a great role in the planning of houses. We could see these effects in designing houses in Cyprus until the first quarter of the XX. Century, during the British Period, realized in parallel with the life culture of the society. Ottoman Period houses in Cyprus, starting with the tent of the nomadic life of Turks in Central Asia, and shaped through the changes and developments in time, have been in conformity with their users, with their multi-functional rooms, with the hall bringing the family together, with their yards formed by story designs, which showed a relationship with earth, without overlooking the climatic data and richness of materials provided by the geography. Houses are generally with two floors and with a yard. Although, places of life functions are mostly on the second floor, there are rooms on the ground floor as well, which is a different feature from Turkish 
Houses in Anatolia. However, rooms facing the street are designed as studios, where daily chores are realized, while other rooms face the hall or the yard so as to retain privacy. Ottoman Period houses, lining down narrow, organic streets in adjacent style, with their plain façades, oriels, and wide eaves keep neighbor relations very strong, which have a very important place in Turkish culture (S. H. Eldem 1987:261) (Photo. 1,2).

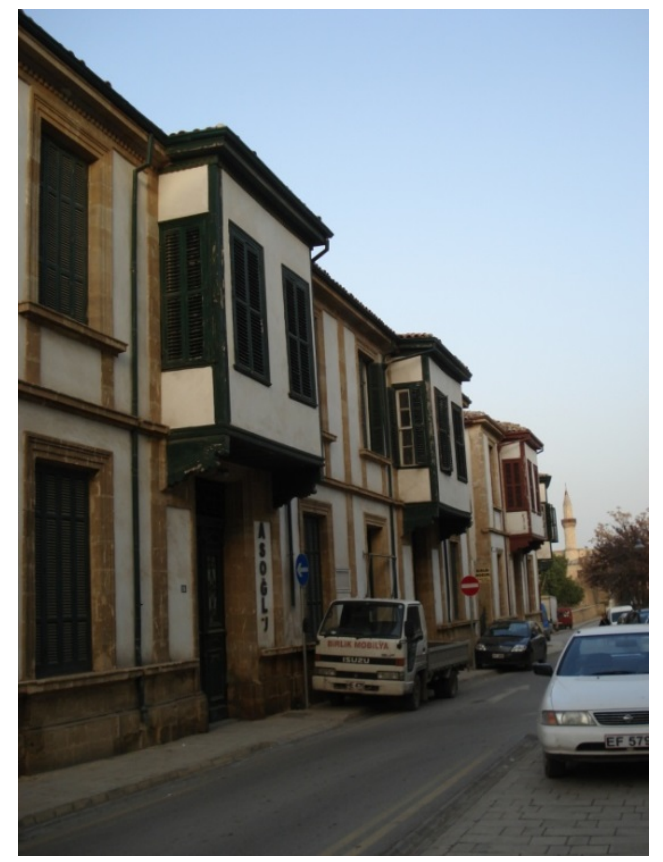

Photo. 1- Turkish Houses in Cyprus (Author)

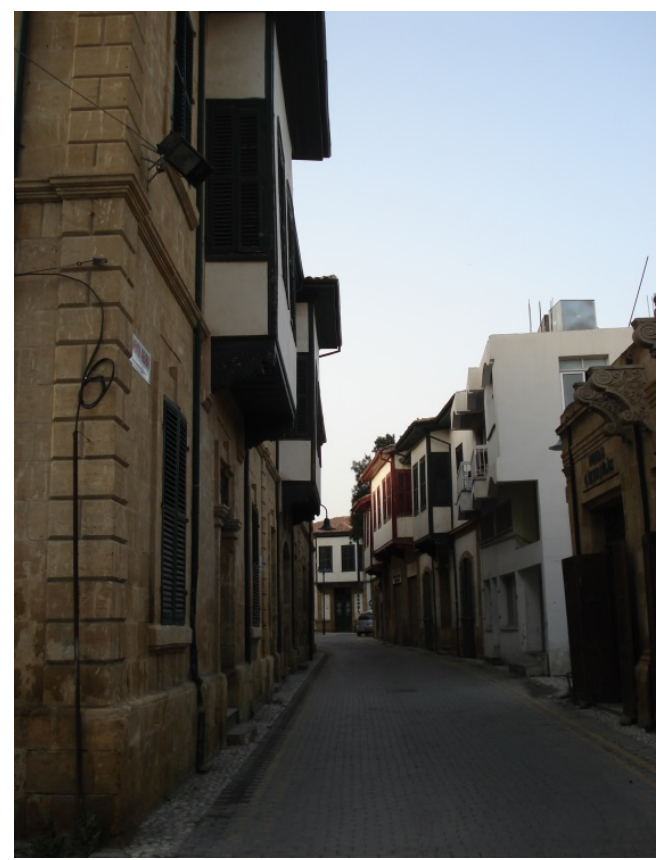

Photo. 2- Turkish Houses in Cyprus (Author)

\section{ROOMS}

Rooms, accepted as the basic element of the Traditional Turkish House (Ö. Küçükerman 1995:91), have taken their place in the design of XIX. Century Ottoman Period houses in Cyprus as the nucleic place, with a quite simple design, and based on the principle of multi-purpose usage. Rooms, carrying the multi-functional characteristic of the single place based tent, which was the initial model of the Turkish House, developed into the square or rectangular form from the circular form of the tent. Rooms, in which the functions of sleeping, eating, child raising, inter-family/close relatives/neighbors relations were realized, were usually designed on the upper floor of two-story houses, at the same time retaining privacy on the fronts facing the street or the hall. Windows opening to the outer façade were either designed in an oblong shape, with a wooden grille, as a top window, or made higher than the floor level, in accordance to human measures, and with wooden shutters to retain privacy. Windows opening to the hall have thick trellis and wooden banisters, providing safety and preventing the room to be seen. Room doors have double wooden wings and open inside the rooms. Room floors are covered with local marble tiles or wooden planks, with rush mats or rugs spread on them. Ceilings are mostly left showing the structure; sometimes covered with wood in a simple fashion.

Using the width of the walls, with are made of the traditional local materials of sand stone or sand brick, niches are created, and used as shelves or glass-winged cupboards. Ceiling heights are designed as 4 to $4.5 \mathrm{~m}$. high, for the hot summer months of the Mediterranean climate. Fireplaces are rare in rooms; heating mostly provided by braziers placed in the middle of the room. On the ground floor, right next to the entrance, opening to the hall or the yard with arches, are oblong shaped large places, having high-level windows with wooden blinds towards the street, which were used as places of work. Providing service especially during the day, these places, adjoining the yard, were used for preparation-production of food, weaving clothing-rugs, and various daily household chores.

Main room: One of the rooms of the Traditional Turkish Houses in Cyprus is the main room. Main room is the largest, best positioned, and most decorated room of the house. It mainly is on the upper floor and guests are entertained there. The main room, usually designed as an oriel towards the street, 
is superior to other rooms. With its oblong shaped windows, side by side, it has the advantage of more natural light and ventilation besides overlooking the street. Sometimes, having a higher elevation than the hall with the help of a few steps, the floor of the main room is styled and decorated with local marble tiles or with wood, using the material in a different direction and size compared to other rooms. The ceiling is always covered with wood and ornamented (H.M. Gürkan 1996:86). Although, ceilings decorated with geometrical figures using stave wood are common, one can come across ornaments of carved wooden figures on the ceilings of some houses. Lamp stands or pot stands, made of carving the walls, either are covered with wood, or are decorated with paint figures. The wooden bordure, or wooden shelf, placed all around the main room, at a level above the top of the door or windows is designed as a functional ornament. The ottomans, stretching along the walls of the main room, especially along the wall facing the street, are placed to accommodate the crowd of the household and guests. The importance given to guests in Turkish traditions is obvious in the importance given to the design of the main room (Photo. 3.4).

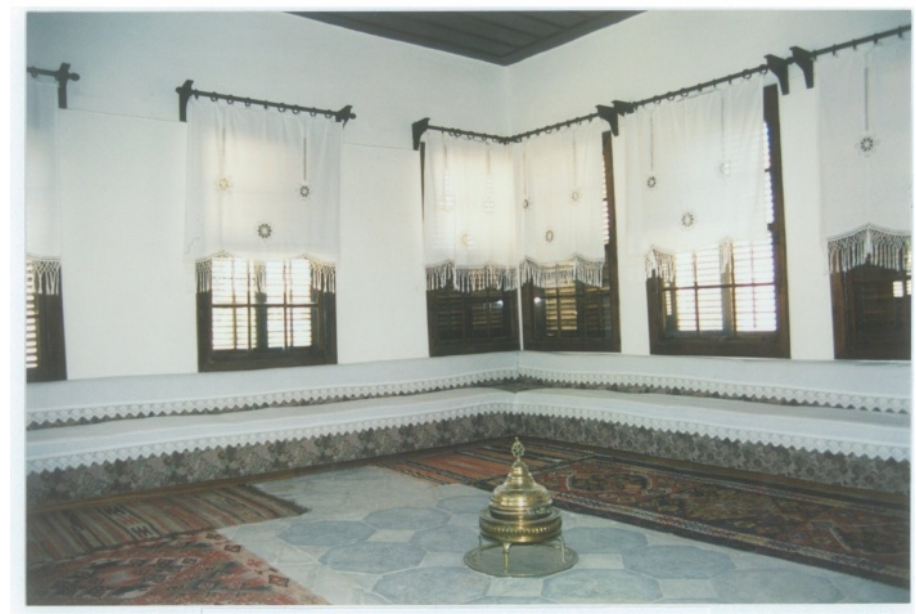

Photo. 3- Main Room of Eaved House - Nicosia (Author)

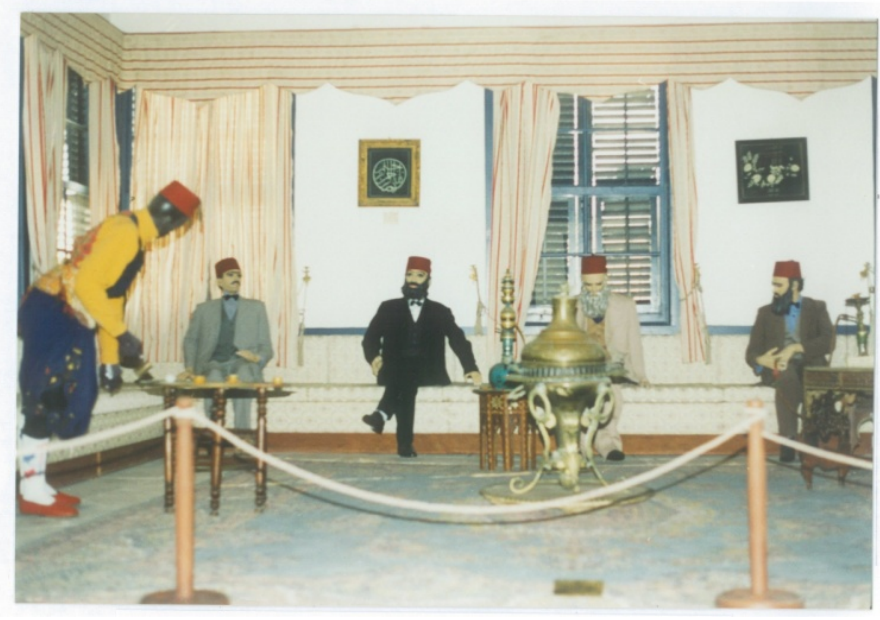

Photo. 4- Main Room of Derviş Pasha Mansion - Nicosia (Author)

\section{HALL}

The hall, being the most important element designating the plan of the Traditional Turkish House, is the common area where relations among rooms are realized (R. Günay 1998:59). Besides being the circulation area of the house, the hall has also been a gathering space with parts of it set aside for sitting (Ö. Küçükerman 1991:59). The plan type of the Turkish house, being applied in accordance with different geography and climatic characteristics, made the Outer Hall Plan more common in Cyprus, which is suitable to the Mediterranean climate. The most important examples of houses in Cyprus dating back to the XIX. Century were built with Outer Halls. During most of the year, when 
the weather was good, and in summer, the hall was the living and production place of the household. The iwans seen in the ground floor and upper floors indicate the life style here. On ground floors, the halls were designed with sharply arched riwaqs, sometimes with columns, made from cut stone blocks. On upper floors, halls had riwaqs on wooden poles, leaning towards the yard, with wooden structured roofs, covered with tiles. The Outer Hall plan type, reflecting the nomadic, tent life of Turks on permanent settlements, created a close encounter with nature, and the XIX. Century Turkish Houses of Cyprus with yards, strengthening the hall-yard relationship, realized a convergence with nature (Photo. 5.6).

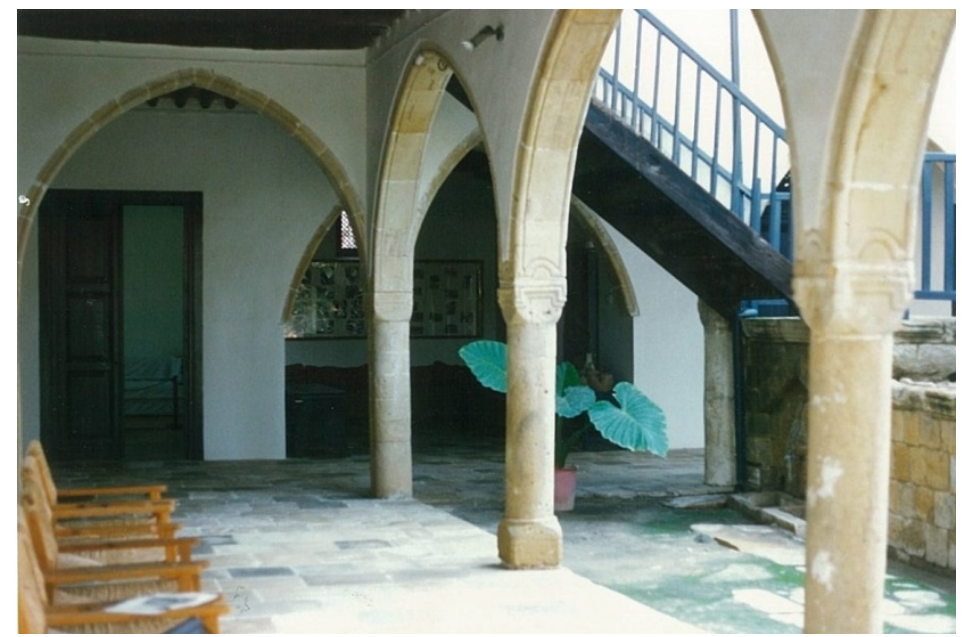

Photo. 5- Hall of Derviş Pasha Mansion - Nicosia (Author)

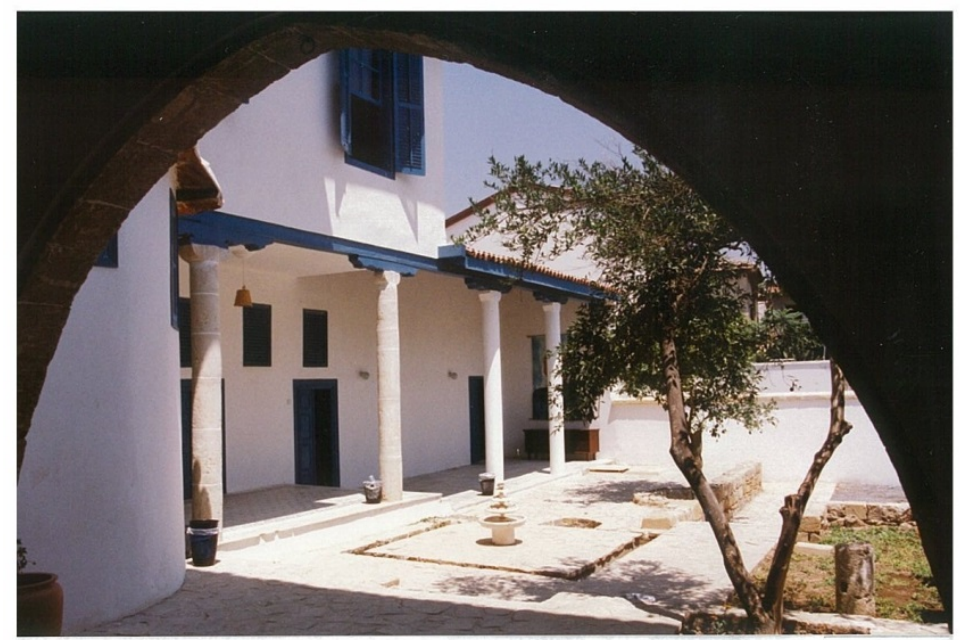

Photo. 6- Hall of Nicosia Turkish House (Author)

Stairs: Stairs, being a part of the hall in Turkish Houses (D. Kuban 1995:147), generally stretches outside the hall, in a parallel position to the hall, as a vertical element of circulation joining the lower and upper halls in the Ottoman Period houses in Cyprus. Stairs with two rails, seen in some houses, are placed in a direct angle to the long side of the hall. The place of the stairs is chosen in a way that it is not visible from the main entrance of the house, with the aim of providing safety and privacy. The first few steps of wooden stairs are made of stone. Besides stairs with all steps made of cut stone, and with two rails, stairs with one rail of stone, and the other wooden are also seen in the Turkish Houses in Cyprus. The stairs were not finished towards the entrance of main rooms. Thus, vertical circulation and life in rooms were isolated, preventing view and noise (Photo. 7). 


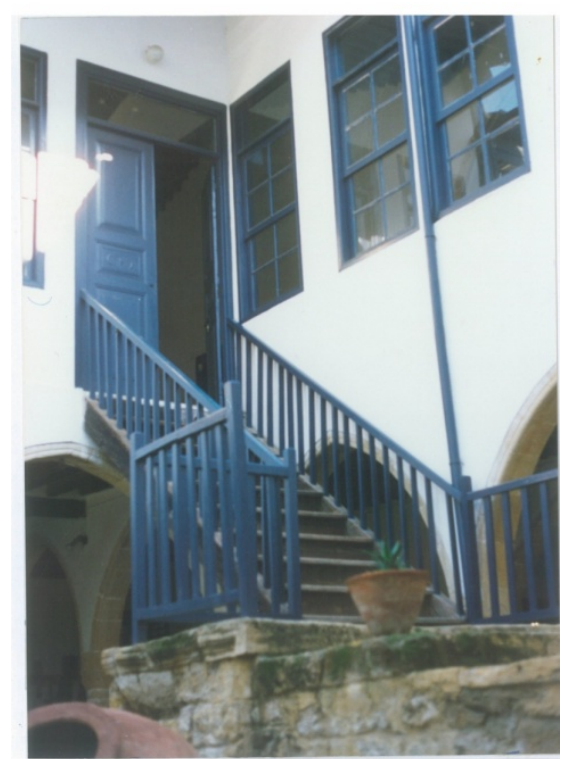

Photo. 7- Stairs of Derviş Pasha Mansion - Nicosia (Author)

\section{YARD}

The importance of relationship with earth in the Turkish life culture comes from nomadic life. In nomadic life, earth was both the source of income, and the common space among tents. With the transition to permanent settlements, the tie with earth continued in the yards of houses. The element of water gave life to the yard through wells and water tanks (C. Bektaş 1996:86). Ottoman Period Turkish Houses were built with yards in Cyprus; Outer Hall Plan type houses intensified the houseyard relationship (T. Salihoğlu 2006:192). Yards were mostly placed in the opposite direction of the street front, special for the life of the household, and surrounded by high walls, providing privacy from neighboring parcels (U. U. Dağl1 1999:62). The yards of large houses, built as mansions, were also accessed from the street through a service door, thus separating life in the house from external services. Besides small-scale agricultural activities meeting the needs of the house, citrus and other fruit trees of the Mediterranean climate were the main occupations in the yards. The date trees found in the yards of the Traditional Turkish Houses of Cyprus were raised by families to symbolize Islam (H. M. Gürkan 2006:41). Water architecture, in the Turkish Houses in Cyprus, was an important element of life culture, for the needs of the house and the yard (H. Hikmetağalar 1996:107). The water well, the water cistern to store water, made of cut stone blocks, the fountain, placed on one side of the cistern, and the gully carved out of stone to run the water to the yard, were positioned in the yard, right next to the hall. The yard was used for various daily chores during the daytime life of the house under the conditions of the Mediterranean climate; while also serving as a place for cooling off during hot summer days (Photo. 8, 9).

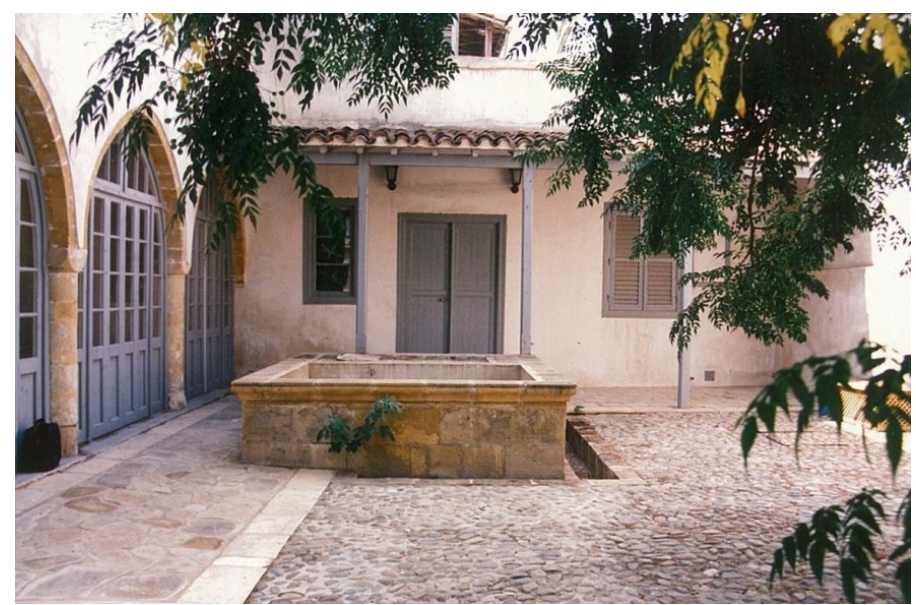

Photo. 8- Yard of Nicosia Turkish House (Author) 


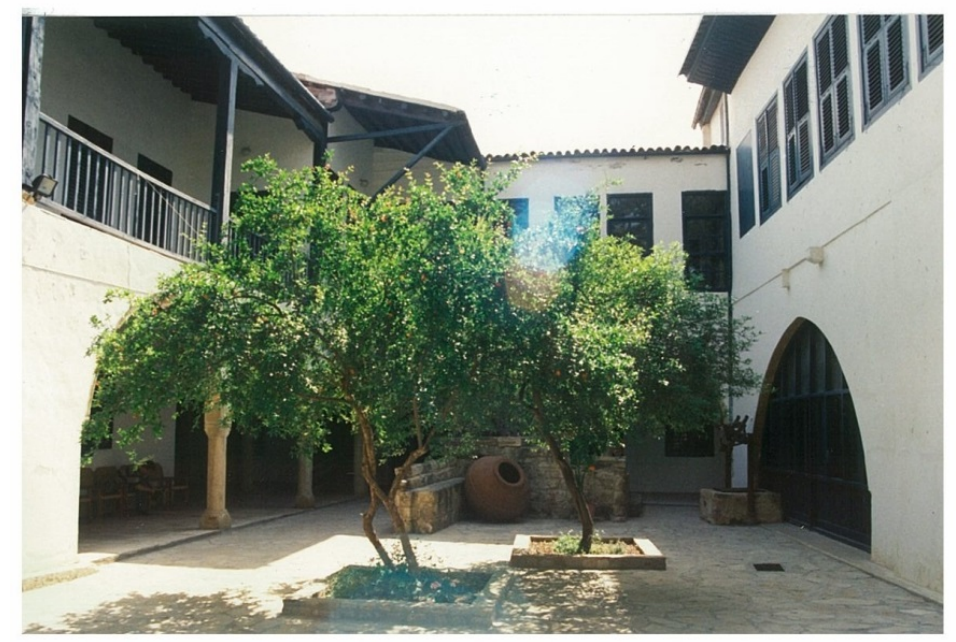

Photo. 9- Yard of Derviş Paşa Mansion - Nicosia (Author)

\section{CONCLUSION}

The vital needs of users, their traditions, and social behaviors have been very effective in the planning of the house as a shelter, and as a spatial concept, that brings the family together. Thus, it has been shaped as a reflection of different cultures of different communities in the world. Beginning with the nomadic life in Central Asia, possessing very old customs and traditions, the houses of Turks, who have distinctive life styles, were designed in a unique way and the notion of "Traditional Turkish House" has taken its place in the architectural literature of the world. The research and examinations carried out within this scope clearly shows that Turkish culture of living, specific to its users have been the most important factor in the shaping of the plan schemes of Turkish Houses in Cyprus during the Ottoman Period (1570-1878).

The Room, which is the space where the daytime and nighttime functions of the family members, sitting, eating, sleeping, inter-family meetings, and simple daily chores take place, is shaped multifunctionally as a reflection of the single space of the tent life of Turks. Multi-functional Rooms generally take place on the upper floor of the houses, with a simple arrangement. Because of the importance of guests in Turkish culture, the guest room is the most important room with its ornaments and its position in the planning, and is named the "Main room," stressing its importance.

Due to the family structure and traditions of Turks, and the importance of relations and sharing, the Hall, as the common space connecting Rooms to each other, has become a meaningful and important element in the Turkish Houses of Cyprus. The Halls, with the opportunities of the Mediterranean climate, are a kind of Outer Halls with riwaqs, strengthening house-yard relationship. The staircase, joining the floors of the house, is designed in a way that conceals it from the main entrance because of the importance given to privacy, and does not end towards the entrance of Rooms. The first step of timber stairs is made of stone.

The relationship of Turks with earth since their nomadic lives, made it important to design Turkish Houses in Cyprus with yards. The yards behind high walls of houses, lined along narrow streets in adjacent form, have the functions of meeting daily and cultural needs. With elements of aqua architecture, such as water well, cistern, and fountain, yards allowed to grow seasonal vegetables, flowers, and fruit trees that also provided shade during hot summer months.

The traditions, forming the life style of Turks, their beliefs, and unique social needs show their effect in all open, semi-open, and closed spaces of Turkish Houses in Cyprus. Local and climatic characteristics also appear as effective criteria in the planning stages of houses. Typical examples of the Traditional Turkish House, the Ottoman Period Turkish Houses in Cyprus still bear conditions of healthy use with their vital functions and positive planning arrangements based on climatic factors, although they have a history exceeding a century and a half. Compared to the contemporary concrete, 
type planned houses, which are incompatible with their users; they possess more useful living spaces, and are good examples of physical and social adequacy.

\section{REFERENCES}

Anonymous. (1982) Kıbrıs'ta Türk Eserleri, Lefkoşa, Kıbrıs Türk Federe Devleti Eğitim, Kültür ve Spor Bakanlığı Eski Eserler ve Müzeler Dairesi Müdürlüğü Yayını.

Bektaş, C. (1996) Türk Evi, İstanbul, Yapı Kredi Yayınları.

Dağlı, U. U. (1999) Kıbrıs Sokaklarında Mimariye Yaşama ve Çevreye Dair, Lefkoşa, Işık Kitabevi Yayınları.

Eldem, S. H. (1968) Türk Evi Plan Tipleri, İstanbul, İstanbul Teknik Üniversitesi Yayını (2. Basım). Eldem, S. H. (1987) Türk Evi Osmanlı Dönemi III, İstanbul, T.A.Ç. Vakfı Yayını.

Günay, R. (1989) Geleneksel Safranbolu Evleri ve Oluşumu, Ankara, Kültür Bakanlığı Yayınları.

Gür, Ş. Ö. (1993) Konut Sorunu Ders Notları, Trabzon, Karadeniz Teknik

Üniversitesi Yayını.

Gür, Ş. Ö. (2000) Doğu Karadeniz Örneğinde Konut Kültürü, İstanbul, YEM

Yayını.

Gürkan, H. M. (1996) Kıbrıs Tarihinden Sayfalar, Lefkoşa, Galeri Kültür Yayınları (3. Baskı).

Gürkan, H. M. (2006) Dünkü ve Bugünkü Lefkoşa, Lefkoşa, Galeri Kültür Yayınları (3. Baskı).

Hikmetağalar, H. (1996) Eski Lefkoşa'da Semtler ve Anılar, İstanbul, Marifet Yayınları.

Kuban, D. (1995) Türk Hayat'lı Evi, İstanbul, T.C. Ziraat Bankası Yayını.

Küçükerman, Ö. (1991) Kendi Mekânının Arayışı İçinde Türk Evi, İstanbul, Türkiye Turing ve Otomobil Kurumu Yayını (4. Basım).

Küçükerman, Ö. (1995) Anadolu Mirasında Türk Evleri, İstanbul, T.C. Kültür Bakanlığı Yayınları. Salihoğlu, T. (2006) Kıbrıs Adasında Konut, Lefkoşa, Dörtrenk Matbaacılık Ltd. 